\title{
Arena Ambiental Local: um olhar etnográfico para a dinâmica política do COMDEMA de Limeira-SP.
}

\author{
Dilan Diego Carli dos Santos*, Roberto Donato da Silva Júnior.
}

\begin{abstract}
Resumo
A participação da sociedade civil efetiva na construção das políticas públicas ambientais a nível local se apresenta como uma medida importante para alcançar respostas que consigam equacionar os impactos ambientais e uma democracia plena. Os Conselhos Municipais de Defesa do Meio Ambiente (COMDEMA) são espaços que se propõem a solucionar essa questão, porém podem também explicitar conflitos e tensões políticas, favorecendo ou contrariando interesses, influenciando nas políticas ambientais locais. Este trabalho se propõe a analisar a dinâmica política do COMDEMA de Limeira - SP, e a partir dessa experiência compreender e explicar a dinâmica dos agentes neste espaço, através de um olhar etnográfico.
\end{abstract}

\section{Palavras-chave:}

COMDEMA Limeira, olhar etnográfico, dinâmica política, conflitos, tensões.

\section{Introdução}

O COMDEMA é um dos conselhos mais antigos do município de Limeira-SP, criado por meio da Lei Municipal n 1.916/1986, anterior a Constituição Federal de 1988 que institucionalizou no país a municipalização das políticas públicas. Ele passou por diversas mudanças no decorrer dos anos, tanto na composição de seus representantes, quanto em seu caráter, se consultivo ou deliberativo. A institucionalização de um conselho dependerá, dentre tantos fatores, de uma capacidade do município em criá-lo, e de como esse processo se dará, se dentro do gabinete ou por demanda da sociedade civil'.

As ações nos municípios possuem a característica de ultrapassarem seus limites geográficos e sua autonomia política, além de evidenciarem conflitos inerentes ao encontro dos interesses existentes ali. Portanto, se faz imprescindível que nas cidades não se gere somente impactos, senão mudança de paradigma da relação com os recursos naturais e a gestão democrática e coletiva das questões socioambientais².

As condicionantes da cultura política do Brasil marcadas por padrões de relações clientelistas, meritocráticas e de interesses criados entre o Estado e a Sociedade representam um ponto importante ao se pensar os tantos esforços existentes para a criação e efetivação de uma gestão municipal democrática e que concretize a cidadania na busca de uma sustentabilidade real e comprometida ${ }^{3}$.

Os COMDEMAs possuem papel fundamental nesta dinâmica, pois foram idealizados justamente com a função de minimizar a condução burocrática voltada apenas para os interesses do poder público, dando a eles, a possibilidade de serem deliberativos e paritários, o que confere-lhes um poder maior de decisão e influência no caminho que as políticas públicas ambientais municipais tomam. Sendo assim a compreensão da dinâmica das relações estabelecidas nesse espaço se faz primordial para sua compreensão e análise de cumprimento quanto ao seu idealizado.

\section{Resultados e Discussão}

Através da leitura das atas do COMDEMA do ano de 2018, bem como o acompanhamento de suas reuniões no primeiro semestre de 2019 e da aplicação de entrevistas etnográficas aos conselheiros foi possível apreender a urgência desse espaço ser mais participativo e refletir os anseios dos que o compõe. Recentemente houve uma plenária para eleição de novos membros para o novo mandato, e tanto Poder Público quanto Sociedade Civil diminuíram sua representação, de 20 cada, para 18 e 15, respectivamente. Em plenário, os conselheiros muitas vezes apenas são reativos a proposição da mesa diretora, propondo pouco.

As pautas discutidas são preestabelecidas e encaminhadas com um período de antecedência para serem lidas, porém pela complexidade de algumas, esse tempo não é suficiente, causando desconforto em alguns conselheiros por não estarem cientes de todo o teor da discussão.

Ainda que atualmente as reuniões ocorrerem mensalmente, não mais bimestralmente, sua realização é em horário comercial, impossibilitando a participação ampla da sociedade civil, seja conselheiro ou não.

\section{Conclusões}

O COMDEMA Limeira apresenta considerável potencial de efetivação democrática, uma vez que tem se esforçado em fazer desse espaço amplo e participativo. Um ponto que se evidenciou como um empecilho para isso foi sua maneira de condução, centralizada, personalista e que enviesa as discussões, por parte da mesa diretora. O plenário apresentou potencial questionador, muitas vezes mudando o rumo das decisões.

\section{Agradecimentos}

Ao Prof. Roberto Donato da Silva Júnior pela orientação e suporte e ao Conselho Nacional de Desenvolvimento Científico e Tecnológico (CNPq) pela concessão da bolsa para dedicação à pesquisa.

\footnotetext{
COUTO, F. F.; CKAGNAZAROFF, I. B. Prefeituras priorizam o desenvolvimento local? Um estudo qualitativo do caso de Montes Claros/MG de acordo com a visão de gestores públicos locais. Administração Pública e Gestão Social, Montes Claros, v. 8, n. 4, p. 225-234, 2016.

2 GIARETTA, J. B. Z; FERNANDES, V.; PHILIPPI JR, A. Desafios e condicionantes da participação social na gestão ambiental municipal no Brasil. O\&S, Salvador, v. 19, n. 62, p. 527 - 548, 2012

JACOBI, P. Poder local, políticas sociais e sustentabilidade. Saúde e
} Sociedade, v. 8, n. 1, p. 31-48, 1999 . 